\title{
The Co-Involvement of Light and Air Temperature in Regulation of Sex Expression in Monoecious Cucumber (Cucumis sativus L.)
}

\author{
Lina Wang ${ }^{1,2 *}$, Xiaoyu Yang 3 , Zhonghai Ren ${ }^{1,2}$, Xiufeng Wang1,2 \\ ${ }^{1}$ College of Horticulture Science and Engineering, Shandong Agricultural University, Tai'an, China \\ ${ }^{2}$ State Key Laboratory of Crop Biology, Tai'an, China \\ ${ }^{3}$ School of Life Sciences, Faculty of Science, The Chinese University of Hong Kong, Hong Kong, China \\ Email: "Inwang007@163.com
}

Received 17 May 2014; revised 18 June 2014; accepted 30 June 2014

Copyright (C) 2014 by authors and Scientific Research Publishing Inc.

This work is licensed under the Creative Commons Attribution International License (CC BY).

http://creativecommons.org/licenses/by/4.0/

(c) (i) Open Access

\section{Abstract}

The combination effects of light and air temperature, which were expressed as photothermal ratio (PTR), on the growth and sex expression of three monoecious cucumbers (Cucumis sativus $\mathrm{L}$. cv. "Xintaimici", "Jinyan 3" and "Jinyan 4") were studied with hydroponics in this research. The results showed that with the increase of PTR, different growth responses were observed in the three cucumber cultivars. In contrast, high PTR (H-PTR, $0.86 \mathrm{~mol} \cdot \mathrm{m}^{-2}$.degree-day $\left.{ }^{-1}\right)$ significantly increased the total number of female nodes and decreased the total number of male nodes of the three monoecious cucumber cultivars compared with cucumbers grown under low PTR (L-PTR, 0.64 $\mathbf{m o l} \cdot \mathbf{m}^{-2}$.degree-day ${ }^{-1}$ ). More photoassimilate was partitioned to fruits of three cucumber cultivars with the increase of PTR, indicating that PTR-mediated femaleness of monoecious cucumber might be attributed to the enhancement of photoassimilate translocation from source organs to sink organs.

Keywords

Cucumber, Growth, Photothermal Ratio, Sex Expression

\section{Introduction}

Flowering may be the most important developmental transition in the lifespan of higher plants and is a key stage

"Corresponding author.

How to cite this paper: Wang, L.N., Yang, X.Y., Ren, Z.H. and Wang, X.F. (2014) The Co-Involvement of Light and Air Temperature in Regulation of Sex Expression in Monoecious Cucumber (Cucumis sativus L.). Agricultural Sciences, 5, 858-863. http://dx.doi.org/10.4236/as.2014.510092 
that directly affects crop yield [1]-[3]. Cucumber (Cucumis sativus L.), a representative of the Cucurbitaceae family, is one of the most important horticultural crops in the world. It can show every type of sex expression including androecious (male flowers only), andromonoecious (staminate and bisexual flowers on the same plant), gynoecious (female flowers only), hermaphroditic (perfect flowers only), monoecious (both male and female flowers on the same plant) and trimonoecious (male, female and bisexual flowers on the same plant) [4] and is thus considered as a model crop for plant sex expression research.

Genetically, three major loci are involved in the sex expression of cucumber plants. They are named as F, M and A [5]. Briefly, the F gene can stimulate femaleness of cucumber, while the $\mathrm{M}$ gene determines whether flowers are unisexual. Recent studies have shown that the $\mathrm{F}$ locus is responsible for a 1-aminocyclopropane-1-carboxylate (ACC) synthase and the ETHYLENE-INSENSITIVE3 gene may be located in the M locus [6]-[8]. The epistasis has been reported between the A locus and the F locus and, therefore, the A gene is another key factor for the femaleness of cucumber [9]. Environmental factors such as photoperiod, temperature, nitrogen application and mechanical stress can also be involved in the regulation of sex expression of cucumber [10]-[15]. For example, the number of pistillate flowers is increased under short photoperiod in monoecious cucumber [12] and in an androecious cucumber [16]. However, Cantliffe [17] reported that photoperiod has no effects on sex expression in cucumber and gherkin. Low temperature conditions can promote femaleness of cucumber [17]-[19], while high temperature can facilitate maleness of cucumber [20].

Monoecy is the most common type of sex expression in cucumber and has been well studied under various environmental conditions in the past decades [20]-[23]. However, the majority of these reported results are obtained under a single environmental variation, which is quite different from the environmental conditions under greenhouse or field. For example, low temperature is often accompanied by short photoperiod or low light intensity, and temperature can be increased at the same time when photoperiod becomes longer or light intensity is enhanced when crops are grown under greenhouse or field conditions. It is thus necessary to clarify how sex expression of monoecious cucumber responds to the combined changes of both or more environmental factors. Here we reported the combination effects of light and air temperature, which were expressed as photothermal ratio (the ratio of radiant energy [moles of photosynthetic $\left(400 \mathrm{~nm}\right.$ to $700 \mathrm{~nm}$ ) photons $\mathrm{m}^{-2}$ ] to thermal energy (degree-day), PTR) [24], on growth and sex expression of three monoecious cucumber cultivars.

\section{Materials and Methods}

\subsection{Plant Materials and Culture Conditions}

Three monoecious cucumber cultivars, "Xintaimici” (kindly offered by Xintai Cucumber Research Institute, Shandong, China), “Jinyan 3” and "Jinyan 4” (purchased from Tianjin Cucumber Institute, Tianjin, China) were used in this experiment, which was carried out in the growth chambers of Shandong Agricultural University, China, from May to August in 2012. Seeds were sown in the plastic box containing substrates and kept in the SANYO incubator (MIR-553, SANYO Electric Co. Ltd, Japan) at $28^{\circ} \mathrm{C}$ for germination after sterilization. At 3 days after sowing (DAS), germinated cucumbers were transferred to the growth chambers (Table 1). At 21 DAS, cucumber seedlings were transplanted to plastic pots containing rock wool and treatments were started (Table 2). Over experiment course, cucumbers were irrigated with a complete cucumber nutrient solution every other day [25]. At 49 DAS, four plants per cultivar per treatment were sampled for determination of growth parameters and sex expression.

\subsection{Determination of Growth Parameters and Sex Expression}

Plant height and internode length were measured from the node of cotyledon to the top of the main plant stem. Leaf area was determined with LI-3100 Area Meter (LI-COR., USA). The number of nodes, female and male

Table 1. Description of environmental conditions in growth chambers before treatment.

\begin{tabular}{|c|c|c|c|c|c|}
\hline \multirow{2}{*}{ Environmental conditions } & \multirow{2}{*}{$\operatorname{PPFD}^{1}\left(\mu \mathrm{mol} \cdot \mathrm{m}^{-2} \cdot \mathrm{s}^{-1}\right)$} & \multicolumn{2}{|c|}{ Air temperature $\left({ }^{\circ} \mathrm{C}\right)$} & \multirow{2}{*}{$\mathrm{CO}_{2}$ concentration $\left(\mu \mathrm{mol} \cdot \mathrm{mol}^{-1}\right)$} & \multirow{2}{*}{$\mathrm{RH}^{2}(\%)$} \\
\hline & & Day & Night & & \\
\hline & 350 & 20 & 20 & 1000 & 70 \\
\hline
\end{tabular}

${ }^{1}$ Photosynthetic photon flow density. ${ }^{2}$ Relative humidity. 
Table 2. Description of the different treatments for observation of sex expression of three cucumber cultivars during the 4week treatment course. $\mathrm{CO}_{2}$ concentration and $\mathrm{RH}$ were set as $1000 \mu \mathrm{mol} \cdot \mathrm{mol}^{-1}$ and $70 \%$, respectively, during treatment period.

\begin{tabular}{|c|c|c|c|c|c|c|c|}
\hline \multirow{2}{*}{ Treatment } & \multicolumn{2}{|c|}{ Air temperature $\left({ }^{\circ} \mathrm{C}\right)$} & \multirow{2}{*}{$\begin{array}{l}\text { Daily average air } \\
\text { temperature }\left({ }^{\circ} \mathrm{C}\right)\end{array}$} & \multirow{2}{*}{ Photoperiod (h) } & \multirow{2}{*}{$\begin{array}{c}\mathrm{PPFD}^{1} \\
\left(\mu \mathrm{mol} \cdot \mathrm{m}^{-2} \cdot \mathrm{s}^{-1}\right)\end{array}$} & \multirow{2}{*}{$\operatorname{DLI}^{2}\left(\mathrm{~mol} \cdot \mathrm{m}^{-2} \cdot \mathrm{d}^{-1}\right)$} & \multirow{2}{*}{$\begin{array}{c}\mathrm{PTR}^{3} \\
\left(\mathrm{~mol} \cdot \mathrm{m}^{-2} \cdot \text { degree-day }^{-1}\right)\end{array}$} \\
\hline & Day & Night & & & & & \\
\hline L-PTR & 25 & 22 & 23.5 & 12 & 350 & 15.12 & 0.64 \\
\hline H-PTR & 25 & 20.4 & 23.5 & 16 & 350 & 20.16 & 0.86 \\
\hline
\end{tabular}

${ }^{1}$ Photosynthetic photon flow density. ${ }^{2}$ Photo thermal ratio. ${ }^{3}$ Daily light integral.

nodes was counted and recorded on each plant, respectively. Dry weight (DW) of roots, stems, leaves and fruits was determined after oven drying.

\subsection{Statistical Analysis}

The results were subjected to one-way analyses of variance (ANOVA) and LSD test with SAS software (Statistica version 6.1, StatSoft, St. Tulsa, OK, USA) and presented as means \pm standard error (SE) of four replicates.

\section{Results and Discussions}

Different growth responses were observed in the three monoecious cucumber cultivars with the increasing of PTR. With respect to cucumbers grown under L-PTR treatment, plant height tended to decrease for three cucumber cultivars under H-PTR (Figure 2(A)). The number of nodes tended to decrease for "Xintaimici", whereas to increase for "Jinyan 3" and "Jinyan 4" with the increasing of PTR (Figure 2(B)). Internode length of three cucumber cultivars under H-PTR was lower than those under L-PTR (Figure 2(C)). Previous study showed that light source can influence cucumber internode length and the lower internode length has been observed in cucumbers grown under fluorescent lamps than those grown under natural light conditions [11]. The decrease tendency of internode length under artificial light conditions may be due to the great difference of spectral distribution between solar irradiation and fluorescent lamps in this research (Figure 1). Compared with cucumbers grown under L-PTR, leaf area of cucumbers decreased for "Xintaimici" and "Jinyan 3" under H-PTR conditions, while the increase tendency in leaf area was observed for "Jinyan 4" under H-PTR treatment (Figure 2(D)). These results suggest that PTR could influence the growth of monoecious cucumber in a cultivar-specific manner.

The total number of female nodes is very important for fruit set and final yield of cucumber and can be influenced by light and air temperature [26]. We here analyzed sex expression of the three monoecious cucumber cultivars under different PTR treatments. The results showed that with the increasing of PTR, the total number
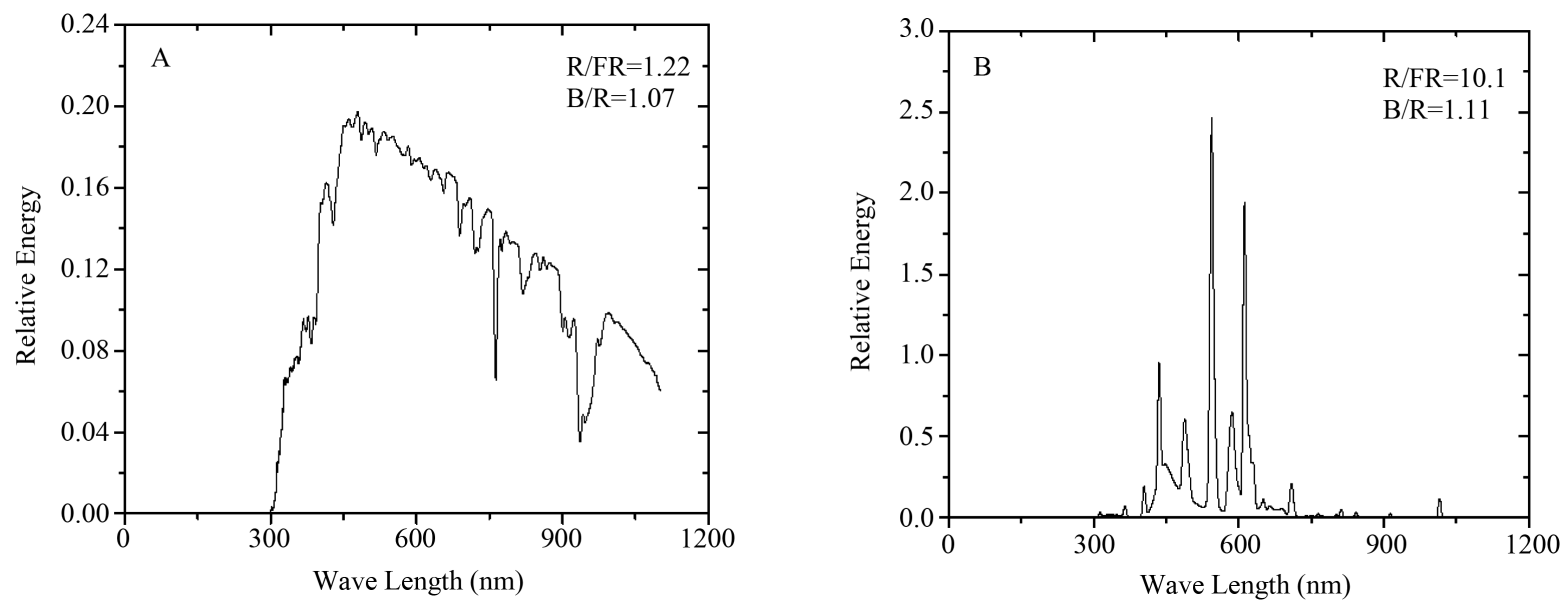

Figure 1. Spectrum distribution of sun light in the field (A) and fluorescence lamp used in this study (B). R/FR and B/R were defined as the ratio of radiant energy of $600 \mathrm{~nm}-700 \mathrm{~nm}$ to $700 \mathrm{~nm}-800 \mathrm{~nm}$ and the ratio of radiant energy of $400 \mathrm{~nm}$ - $500 \mathrm{~nm}$ to $600 \mathrm{~nm}-700 \mathrm{~nm}$, respectively. 

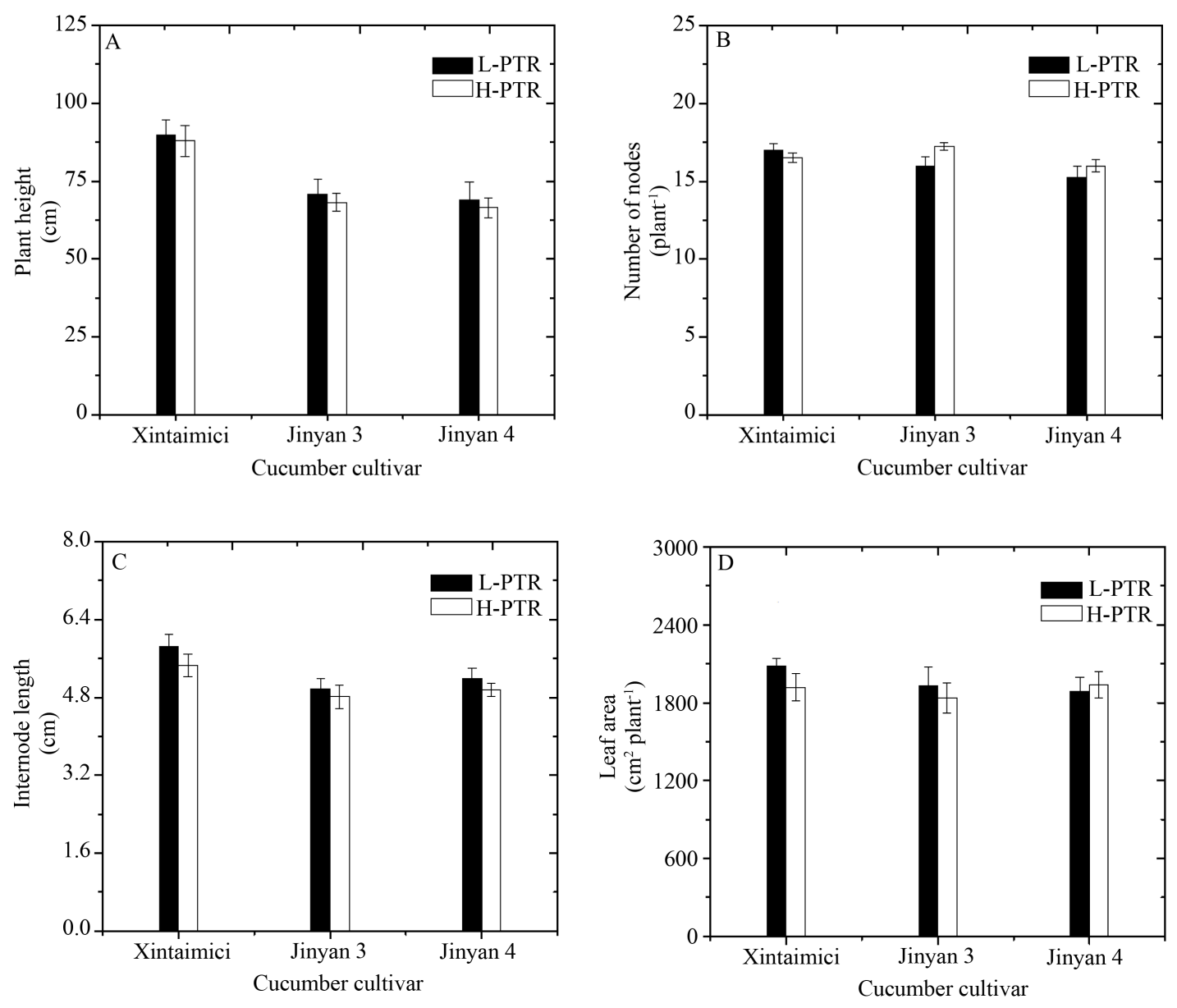

Figure 2. Effects of photothermal ratio (PTR) on plant height (A), number of nodes (B), internode length (C) and leaf area (D) of three monoecious cucumbers. Cucumbers of "Xintaimici”, "Jinyan 3" and "Jinyan 4" were growth under $0.64 \mathrm{~mol} \cdot \mathrm{m}^{-2}$.degree-day ${ }^{-1}$ of PTR (L-PTR) and $0.86 \mathrm{~mol} \cdot \mathrm{m}^{-2}$.degree-day ${ }^{-1}$ of PTR (H-PTR) from 21 days after sowing (DAS) to 49 DAS, respectively. Error bars represent \pm standard errors of the means $(n=4)$.

of female nodes per plant was significantly increased, while the total number of male nodes per plant was significantly decreased for three cultivars (Figure 3), demonstrating that light and air temperature might be co-involved in the regulation of sex expression in monoecious cucumber. Previous studies suggested that sugar is a positive regulator for femaleness and fruit development of cucumber [20] [27] [28]. Competition for photoassimilate between source organs and sink organs is considered as a key reason for sex alterations and fruit abortion in cucumber (27). Therefore, the alleviation of this competition might significantly increase the number of female flowers and reduce fruit abortion in cucumber production. In order to clarify whether the increasing of PTR could alleviate the competition for photoassimilate between vegetative organs and reproductive organs of cucumbers, we determined the dry weight of different organs at the end of treatment course. We found that there were no significant differences in dry weight of roots, stems and leaves for three cultivars under L-PTR and H-PTR (Table 3). In contrast, the increasing of PTR was significantly increased the total dry weight of fruit per plant for three cultivars (Table 3). This evidence indicates that the combination effects of light and air temperature on sex expression of monoecious cucumber might be attributed to the alleviation of the competition for photoassimilate between vegetative organs and reproductive organs.

\section{Conclusion}

PTR is positively involved in the femaleness of monoecious cucumber and its effects on the growth of monoecious cucumber are shown in a cultivar-specific manner. 


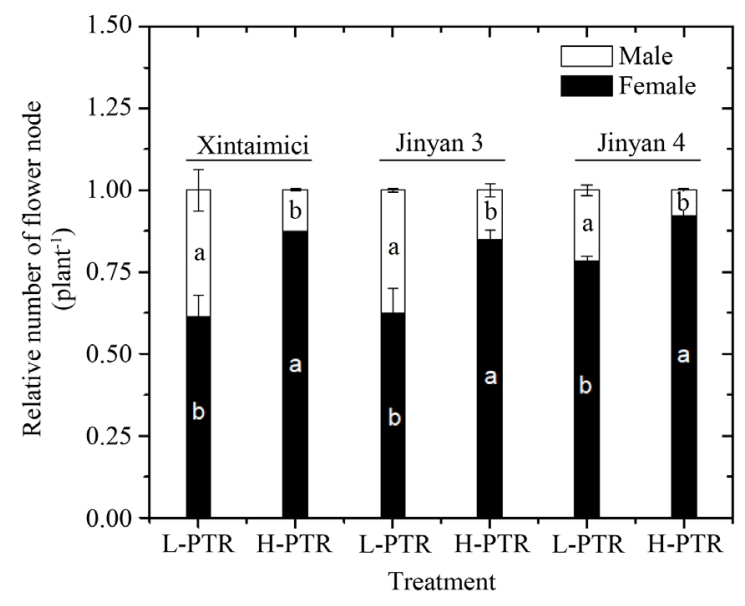

Figure 3. Effects of photothermal ratio (PTR) on the number of female and male nodes in three monoecious cucumbers. Cucumbers of "Xintaimici”, "Jinyan 3" and "Jinyan 4 " were growth under $0.64 \cdot \mathrm{mol} \cdot \mathrm{m}^{-2}$. degree-day ${ }^{-1}$ of PTR (L-PTR) and $0.86 \mathrm{~mol} \cdot \mathrm{m}^{-2}$. degree-day ${ }^{-1}$ of PTR (H-PTR) from 21 days after sowing (DAS) to 49 DAS, respectively. Error bars represent \pm standard errors of the means $(n=4)$. Different letters indicate significant difference between the treatments at 0.05 level.

Table 3. Dry weight of root, stem, leaf and fruit of three monoeciuos cucumber cultivars grown under different PTR.

\begin{tabular}{|c|c|c|c|c|c|c|c|c|c|c|c|c|}
\hline \multirow[b]{2}{*}{ Treatment } & \multicolumn{4}{|c|}{ "Xintaimici” } & \multicolumn{4}{|c|}{ “Jinyan 3” } & \multicolumn{4}{|c|}{ “Jinyan 4” } \\
\hline & $\begin{array}{c}\text { Root dry } \\
\text { weight } \\
\left(\mathrm{g} \cdot \text { plant }^{-1}\right)\end{array}$ & $\begin{array}{l}\text { Stem dry } \\
\text { weight } \\
\left(\mathrm{g} \cdot \text { plant }^{-1}\right)\end{array}$ & $\begin{array}{l}\text { Leaf dry } \\
\text { weight } \\
\left(\mathrm{g} \cdot \text { plant }^{-1}\right)\end{array}$ & $\begin{array}{c}\text { Fruit dry } \\
\text { weight } \\
\left(\mathrm{g} \cdot \text { plant }^{-1}\right)\end{array}$ & $\begin{array}{l}\text { Root dry } \\
\text { weight } \\
\left(\mathrm{g} \cdot \text { plant }^{-1}\right)\end{array}$ & $\begin{array}{l}\text { Stem dry } \\
\text { weight } \\
\left(\mathrm{g} \cdot \text { plant }^{-1}\right)\end{array}$ & $\begin{array}{c}\text { Leaf dry } \\
\text { weight } \\
\left(\mathrm{g} \cdot \text { plant }^{-1}\right)\end{array}$ & $\begin{array}{c}\text { Fruit dry } \\
\text { weight } \\
\left(\mathrm{g} \cdot \text { plant }^{-1}\right)\end{array}$ & $\begin{array}{l}\text { Root dry } \\
\text { weight } \\
\left(\mathrm{g} \cdot \text { plant }^{-1}\right)\end{array}$ & $\begin{array}{l}\text { Stem dry } \\
\text { weight } \\
\left(\mathrm{g} \cdot \text { plant }^{-1}\right)\end{array}$ & $\begin{array}{c}\text { Leaf dry } \\
\text { weight } \\
\left(\mathrm{g} \cdot \text { plant }^{-1}\right)\end{array}$ & $\begin{array}{l}\text { Fruit dry } \\
\text { weight } \\
\left(\mathrm{g} \cdot \text { plant }^{-1}\right)\end{array}$ \\
\hline L-PTR & $1.56 \pm 0.08$ & $3.46 \pm 0.07$ & $9.10 \pm 0.13$ & $14.23 \pm 0.24$ & $1.32 \pm 0.06$ & $2.51 \pm 0.06$ & $6.81 \pm 0.13$ & $13.76 \pm 0.13$ & $1.77 \pm 0.10$ & $2.92 \pm 0.07$ & $7.24 \pm 0.14$ & $14.58 \pm 0.22$ \\
\hline H-PTR & $1.52 \pm 0.05$ & $3.34 \pm 0.07$ & $8.90 \pm 0.13$ & $16.72 \pm 0.15$ & $1.36 \pm 0.09$ & $2.46 \pm 0.06$ & $6.62 \pm 0.10$ & $15.99 \pm 0.21$ & $1.72 \pm 0.10$ & $3.08 \pm 0.07$ & $7.36 \pm 0.12$ & $16.98 \pm 0.19$ \\
\hline
\end{tabular}

Note: All data are the means \pm standard error (SE) of 4 replicates. *represents that the values in the same column have significant differences at 0.05 level.

\section{Acknowledgements}

This work was supported by Research Award Fund for Outstanding Middle-aged and Young Scientist of Shandong Province (NO. BS2011NY010), Research Fund for the Doctoral Program of Higher Education of China (20113702120008) and the China Agriculture Research System (CARS-25-D).

\section{References}

[1] Terefe, D. and Tatlioglu, T. (2005) Isolation of a Partial Sequence of a Putative Nucleotide Sugar Epimerase, Which May Involve in Stamen Development in Cucumber (Cucumis sativus L.). Theoretical and Applied Genetics, 111, 13001307. http://dx.doi.org/10.1007/s00122-005-0058-4

[2] Chen, H., Tian, Y., Lu, X. and Liu, X. (2011) The Inheritance of Two Novel Subgynoecious Genes in Cucumber (Cucumis sativus L.). Scientia Horticulturae, 127, 464-467. http://dx.doi.org/10.1016/j.scienta.2010.11.004

[3] Yang, X., Wang, X., Wang, L. and Wei, M. (2012) Control of Light Environment: A Key Technique for High-Yield and High-Quality Vegetable Production in Protected Farmland. Agricultural Sciences, 3, 923-928. http://dx.doi.org/10.4236/as.2012.37112

[4] Kielkowska, A. (2013) Sex Expression in Monoecious Cucumbers Micropropagated in Vitro. Biologia Plantarum, 57, 725-731. http://dx.doi.org/10.1007/s10535-013-0342-0

[5] Zhang, J., Boualem, A., Bendahmane, A. and Ming, R. (2014) Genomics of Sex Determination. Current Opinion in Plant Biology, 18, 110-116. http://dx.doi.org/10.1016/j.pbi.2014.02.012 
[6] Liu, S., Xu, L., Jia, Z., Xu, Y., Yang, Q., Fei, Z., Lu, X., Chen, H. and Huang, S. (2008) Genetic Association of ETHYLENE-INSENSITIVE3-Like Sequence with the Sex Determining M Locus in Cucumber (Cucumis sativus L.). Theoretical and Applied Genetics, 117, 927-933. http://dx.doi.org/10.1007/s00122-008-0832-1

[7] Li, Z., Huang, S., Liu, S., Pan, J., Zhang, Z., Tao, Q., Shi, Q., Jia, Z., Zhang, W., Chen, H., Si, L., Zhu, L. and Cai, R. (2009) Molecular Isolation of the M Gene Suggests That a Conserved-Residue Conversion Induces the Formation of Bisexual Flowers in Cucumber Plants. Genetics, 182, 1381-1385. http://dx.doi.org/10.1534/genetics.109.104737

[8] Li, Z., Wang, S., Tao, Q., Pan, J., Si, L., Gong, Z. and Cai, R. (2012) A Putative Positive Feedback Regulation Mechanism in CsACS2 Expression Suggests a Modified Model for Sex Determination in Cucumber (Cucumis sativus L.). Journal of Experimental Botany, 63, 4475-4484. http://dx.doi.org/10.1093/jxb/ers123

[9] Tanurdzic, M. and Banks, J.A. (2004) Sex-Determining Mechanisms in Land Plants. The Plant Cell, 16, S61-S71. http://dx.doi.org/10.1105/tpc.016667

[10] Ito, H. and Saito, T. (1958) Factors Responsible for Sex Expression of Japanese Cucumber. IX. Effects of Nitrogen Application and Watering under the Controlled Day Length and Night Temperature in the Nursery Bed. Journal of the Japanese Society for Horticultural Science, 27, 11-19. http://dx.doi.org/10.2503/jjshs.27.11

[11] Ito, H. and Saito, T. (1960) Factors Responsible for Sex Expression of Japanese Cucumber. XII. Physiological Factors Associated with the Sex Expression of Flowers. Tohoku Journal of Agricultural Research, 11, 287-308.

[12] Atsmon, D. and Galun, E. (1962) Physiology of Sex in Cucumis sativus (L.) Leaf Age Patterns and Sexual Differentiation of Floral Buds. Annals of Botany, 26, 137-146.

[13] Galun, E. (1962) Study of the Inheritance of Sex Expression in the Cucumber. The Interaction of Major Genes with Modifying Genetic and Non-Genetic Factors. Genetica, 32, 134-163. http://dx.doi.org/10.1007/BF01816091

[14] Takahashi, H. and Suge, H. (1980) Sex Expression in Cucumber Plants as Affected by Mechanical Stress. Plant and Cell Physiology, 21, 303-310.

[15] Bachman, G.R. and McMahon, M.J. (1997) Light Quality Effects on Flower Sex Expression in Cucumber and Spinach. HortScience, 32, 464.

[16] Rudich, J., Baker, L.R., Scott, J.W. and Sell, H.M. (1976) Phenotypic Stability and Ethylene Evolution in Androecious Cucumber. Journal of the American Society for Horticultural Science, 101, 48-51.

[17] Cantliffe, D.J. (1981) Alteration of Sex Expression in Cucumber Due to Changes in Temperature, Light Intensity and Photoperiod. Journal of the American Society for Horticultural Science, 106, 133-136.

[18] Ito, H. and Saito, T. (1957) Factors Responsible for Sex Expression of Japanese Cucumber. VI. Effects of the Daylength and Night Temperature, Unsuitable for the Pistillate Flower Formation, Artificially Controlled during the Various Stages of Seedling Development in the Nursery Bed. Journal of the Japanese Society for Horticultural Science, 26, 1-8. http://dx.doi.org/10.2503/jjshs.26.1

[19] Fukushima, E., Matsuo, E. and Fujieda, K. (1968) Studies on the Growth Behaviour of Cucumber, Cucumis sativus L. I. The Types of Sex Expression and Its Sensitivity to Various Daylength and Temperature Conditions. Journal of the Faculty of Agriculture Kyushu University, 14, 349-366.

[20] Miao, M., Yang, X., Han, X. and Wang, K. (2011) Sugar Signaling Is Involved in the Sex Expression Response of Monoecious Cucumber to Low Temperature. Journal of Experimental Botany, 62, 797-804. http://dx.doi.org/10.1093/jxb/erq315

[21] Matsubara, S. (1977) In Vitro Modification of Sex Expression of Cucumber by Plant Growth Regulators. Scientific Reports of the Faculty of Agriculture, Okayama University, Okayama, 15-23.

[22] Chailakhyan, M.Kh. (1979) Genetic and Hormonal Regulation of Growth, Flowering and Sex Expression in Plants. American Journal of Botany, 66, 717-736. http://dx.doi.org/10.2307/2442417

[23] Malepszy, S. and Niemirowicz-Szczytt, K. (1991) Sex Determination in Cucumber (Cucumis Sativus) as a Model System for Molecular Biology. Plant Science, 80, 39-47. http://dx.doi.org/10.1016/0168-9452(91)90271-9

[24] Liu, B. and Heins, R.D. (2002) Photothermal Ratio Affects Plant Quality in “Freedom” Poinsettia. Journal of America Society for Horticultural Science, 127, 20-26.

[25] Guo, S.R. (2004) Soilless Culture. China Agricultural Press, Beijing, 114.

[26] Wang, L., Yang, X., Ren, Z. and Wang, X. (2014) Regulation of Photoassimilate Distribution between Source and Sink Organs of Crops through Light Environment Control in Greenhouses. Agricultural Sciences, 5, 250-256. http://dx.doi.org/10.4236/as.2014.54028

[27] Hikosaka, S. and Sugiyama, N. (2005) Effect of Fruit-Load on Growth Patterns of Fruits at the Middle Nodes of Gynoecious-Type Cucumbers. The Journal of Horticultural Science \& Biotechnology, 80, 130-134.

[28] Boonkorkaew, P., Tazuke, A., Hikosaka, S., Mine, Y. and Sugiyama, N. (2011) Effects of Fruit Load on Fruit Growth, Mesocarp Starch Grain Appearance and Sucrose-Catalysing Enzyme Activity in a Gynoecious Cucumber Fruit. Environment Control in Biology, 49, 119-125. http://dx.doi.org/10.2525/ecb.49.119 
Scientific Research Publishing (SCIRP) is one of the largest Open Access journal publishers. It is currently publishing more than 200 open access, online, peer-reviewed journals covering a wide range of academic disciplines. SCIRP serves the worldwide academic communities and contributes to the progress and application of science with its publication.

Other selected journals from SCIRP are listed as below. Submit your manuscript to us via either submit@scirp.org or Online Submission Portal.
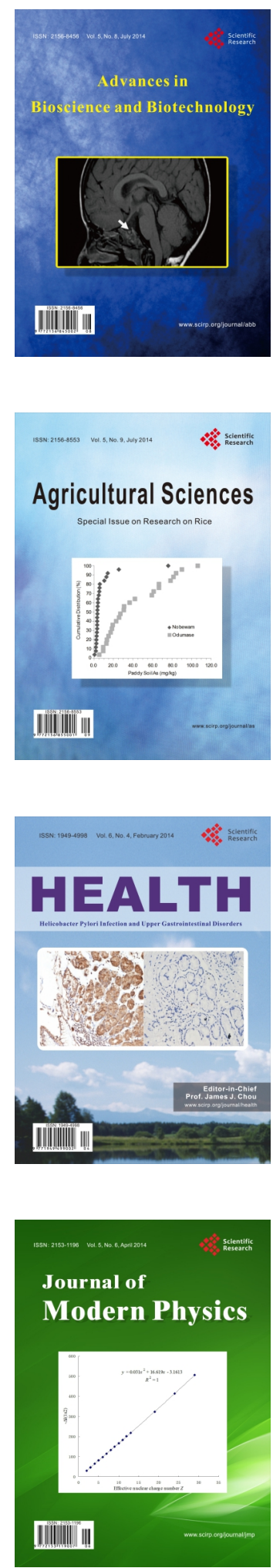
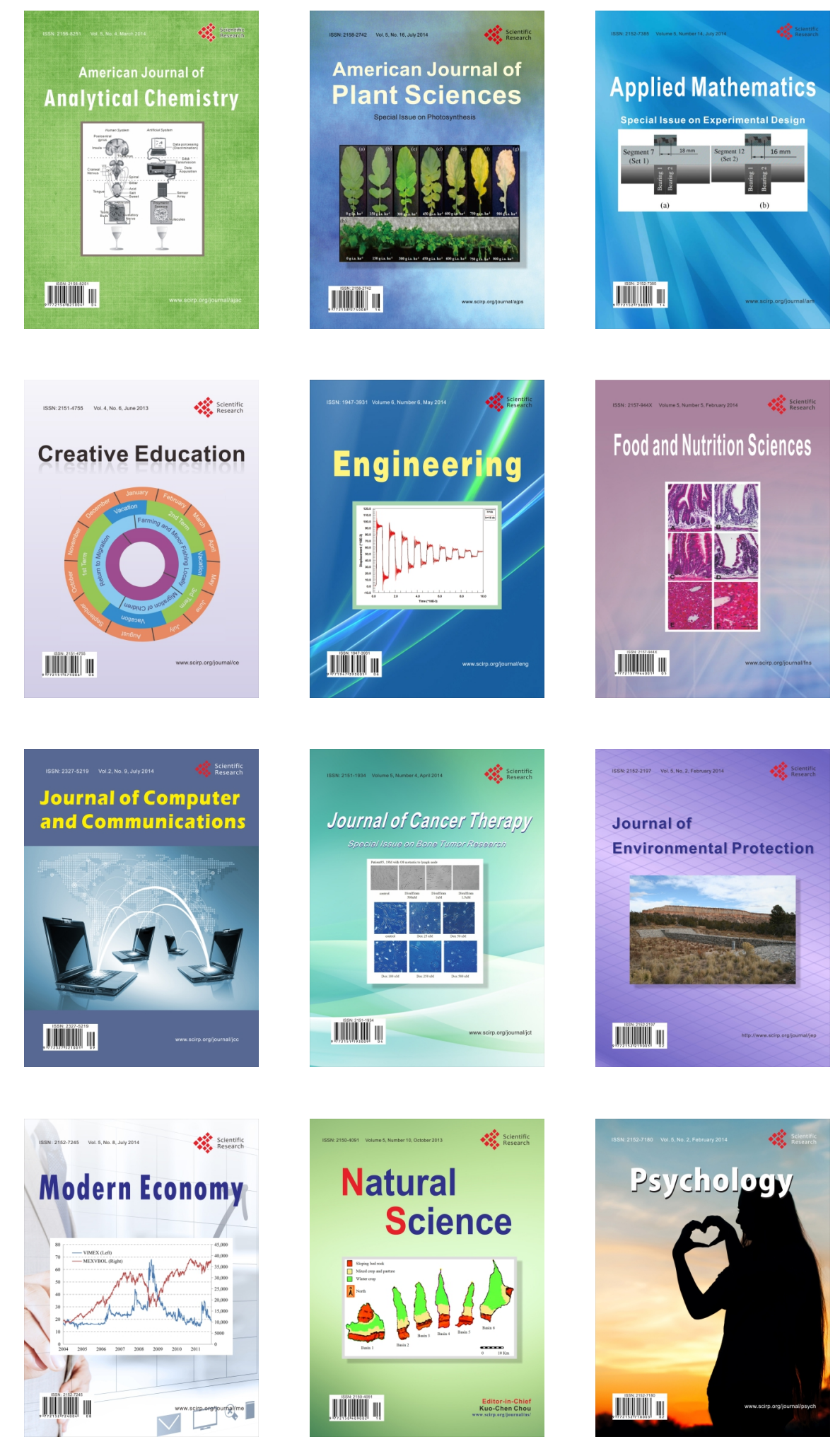